\title{
RESPONSE OF SOME PLANT SPECIES TOWARDS THE ALLELOPATHY OF TWO TYPES OF CHICKPEA (CICER ARIETINUM L.) SEED EXTRACTS
}

\author{
AshtI, S. A. ${ }^{1}-$ Hero, F. H. K. ${ }^{1}-$ Dlshad, A. O. ${ }^{2}-$ NAWROZ, A. T..$^{3 *}$ \\ ${ }^{1}$ University of Sulaimani, College of Agricultural Sciences, Crop Science Department \\ Sulaimani, Iraq \\ ${ }^{2}$ Ministry of Agriculture, General Directorate of Agriculture, Sulaimani, Iraq \\ ${ }^{3}$ University of Sulaimani, College of Agricultural Sciences, Horticulture Department \\ Sulaimani, Iraq \\ *Corresponding author \\ email: nawroz.tahir@univsul.edu.iq \\ (Received $13^{\text {th }}$ Sep 2018; accepted $12^{\text {th }}$ Nov 2018)
}

\begin{abstract}
The investigation was planned to study the chemical composition and allelopathic consequence of two types of chickpea against three weeds of the chickpea crop by using ethanolic extracts. The experiment was carried out in the University of Sulaimani, College of Agricultural Sciences, Sulaimani, Iraq. The extracts of two types, kabuli and black desi seeds, were analyzed by GC/MS, showing that the main constituents of eugenol $(86.35 \%)$, beta caryophyllene $(6.56 \%)$ and caryophyllene oxide $(5.24 \%)$ for black desi seeds and eugenol (89.67\%) and methoxy acetic acid, 3-tridecyl ester (3.47\%) for kabuli seeds. The results showed that all seed extracts displayed significant allelopathic impact, whilst, the powerful of allelopathy of two types of chickpea differ from species to species of weeds. Based on the outcomes, the kabuli seed ethanolic extract showed the maximum degree of seed germination percentage inhibition of all plant species. The extracts acquired from the two types of chickpea caused significant reduction in radical and shoot length of all plant species. Based on the consequences, it can be determined that chickpea types exhibited good allelopathic potential that may be utilized in future as bio-herbicide screening program to launch in the market.
\end{abstract}

Keywords: kabuli and desi chickpea, chemical composition, GC/MS, allelopathy, weeds

\section{Introduction}

Chickpea (Cicer arietinum L.) is one of the most broadly grown leguminous crops in the world. It grows in tropical, subtropical, and temperate climates and provides abundant protein for human diet and animal feeding (Smýkal et al., 2015). The chickpea is a component of the diet in the semiarid tropics as it is a rich source of both protein (8.86\% protein) and carbohydrates $(27.42 \%)$, which comprise $80 \%$ of the whole mass of dry seed; it is free of cholesterol and is a source of dietary fiber, vitamins, minerals, folate, $b$-carotene, and health-promoting fatty acids. There is slight scientific indication concerning the valuable effect on the health of the constituents in chickpea. However, it is reported that the consumption of chickpea reduced the risk of some chronic diseases (el-Adawy, 2002; Yadav et al., 2007; Chibbar et al., 2010; Jukanti et al., 2012; Asif et al., 2013). Seeds of chickpea have been used in Asia and other locations of the world to prepare a variety of fresh, fermented and dried foods (Asif et al., 2013). Chickpea contains numerous bioactive phytochemicals such as phenolic acids, flavonoids, isoflavones, saponins, phytosterols and sphingolipids (López-Cortez et al., 2016). Several studies have shown that legumes commonly hold significant quantities of 
polyphenols, flavonoids, and antioxidant activity that vary widely depending on its type. For example, chickpea color has many polyphenols and flavonoids with high antioxidant potential but the common chickpea beige seeds have little levels of these components with a little antioxidant effect (Xu and Chang, 2010; López-Cortez et al., 2016). Nevertheless, both of them can be utilized for investigations of functional foods.

The yield of chickpea in the developed countries is much more as compared to Iraq and the factors responsible for low yield in Iraq are poor soil, inadequate moisture, harsh climatic conditions, weeds and inadequate fertilizer supply. Weeds compete the crops for moisture, nutrients and light. Many researches have established that chemical constituents with allelopathic effects are existent in leaves, stems, flowers, roots, seeds and buds. The superior weed suppressing genotypes have been reported in in several crops (Vogt et al., 2013; Mahajan et al., 2014). The practice of allelopathic extracts is low-cost and environment gracious. These allelochemicals present major potential to be applied as pesticides because they are free from problems related to the contaminations by pesticides. In order to provide more precise information regarding the negative impact and chemical compositions of different genotypes of chickpea, this work aimed to define the chemical profile and possible ill effect of different extracts collected from various genotypes of chickpea on some germination parameters of weeds under laboratory conditions.

\section{Materials and methods}

\section{Plant materials}

The chickpea seeds, kabuli and black desi types, were collected in June, 2017 from the Agricultural Research Station, Ministry of Agriculture in Sulaimani, Kurdistan region, Iraq. The seeds were collected from 50 plants. All laboratory experiments were achieved at the University of Sulaimani, College of Agricultural Sciences, Sulaimani, Iraq in 2018.

\section{Ethanolic extracts seeds isolation}

The seed of fifty plants was crushed, using a grinding machine. The crushed seeds of kabuli and black desi chickpea (20 g) were placed into the thimble $(25-\mathrm{x}$ 80-mm thimble), which is loaded inside the Soxhlet extractor (BÜCHI Extraction System Model B-811, Switzerland) (Fig. 1). An amount of $220 \mathrm{ml}$ of pure ethanol (Merck) was placed in a bottom flask, which was connected to a Soxhlet extractor and condenser. The ethanol was heated and started to evaporate, moving to the condenser. The condensate drops, then dripped into the reservoir containing the thimble. Once the level of ethanol reaches the siphon it discharges back into the flask and the cycle begins again. The process continued for a total of $130 \mathrm{~min}$. The extracts were dried by utilizing a vacuum rotary evaporator and the dried samples were weighted.

\section{Analyses of ethanol extraction by GC/MS}

Seed extract composition was analyzed and accomplished at the University of Sulaimani, College of Agricultural Sciences, Iraq. The GC/MS analysis was attained by using Shimadzu GC-QP 2010 Ultra gas chromatograph (Japan). The GC oven temperature was stated at $40{ }^{\circ} \mathrm{C}$ and then progressively raised to $280{ }^{\circ} \mathrm{C}$ at a rate of 15 ${ }^{\circ} \mathrm{C} / \mathrm{min}$. Helium was exploited as a hauler gas; inlet pressure was $96.1 \mathrm{kPa}$; linear 
velocity was $47.2 \mathrm{~cm} \mathrm{sec}^{-1}$. Column flux was $1.71 \mathrm{ml} / \mathrm{min}$; injector temperature $280{ }^{\circ} \mathrm{C}$; injection mode: split. MS scan conditions: source temperature $200{ }^{\circ} \mathrm{C}$; interface temperature $280{ }^{\circ} \mathrm{C}$; detector gain $0.69 \mathrm{kV}+0.10 \mathrm{kV}$ and mass range of $\mathrm{m} / \mathrm{z} 50-800$. The elements of the extracts were set by matching the retention indices with those of documented components stored in the NIST library (2005) or either those of the literature. Peak area concentrations of the constituents were calculated to rely on GC peak areas.

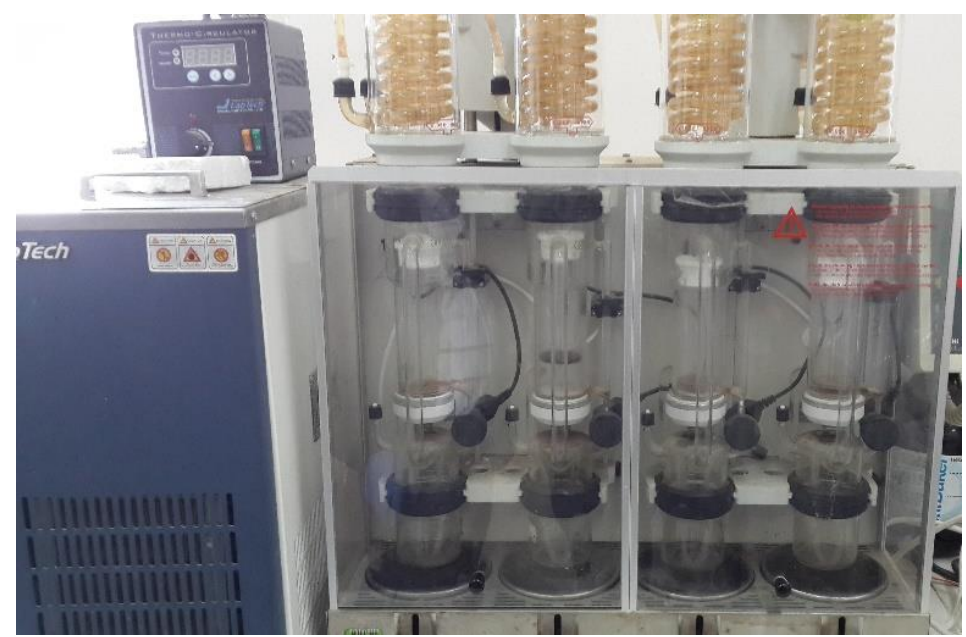

Figure 1. Soxhlet apparatus (BÜCHI Extraction System Model B-811) used in this study

\section{Plant species and Allelopathy assay}

The inhibition potential of the extracts collected from kabuli and black desi seed on seed germination, and growth elongations of plant species: common vetch (Vicia sativa), wild mustard (Sinapis arvensis L.), wild narbon vetch (Vicia narbonensis L.) and chickpea (Cicer arietinum L.) was achieved. Plant species seeds were sterilized for 9 min with $\mathrm{NaClO}(0.90 \%)$ and then washed six times with autoclaved distilled water. Three replicates, each comprising of 15 seeds, were exercised in each of the control, 2.00 and $4.00 \mathrm{mg} / \mathrm{ml}$ extracts, using sterile petri dishes $(9.00 \mathrm{~cm}$ diameter $)$ padded with three-sterile filter papers (Whatman). The extracts were diluted in a distilled wateracetone (Merck) mixture (98:2) (Formisano et al., 2007). Seven ml of distilled water/acetone (control) or $7 \mathrm{ml}$ different doses of the two plant extracts (2.00 and 4.00 $\mathrm{mg} / \mathrm{ml}$ ) was added to each petri dishes. Controls were verified with this mixture (wateracetone mixture (98:2)) alone exhibited no considerable variances. The dishes were wrapped with parafilm to avoid the losses of moisture and to prevent the microbial contaminations and set in a growth chamber in the dark at $25^{\circ} \mathrm{C} \pm 1$ for 7 days. After seven days, the germination percentage and seedling elongation were determined. A seed was estimated germinated when the radicle become obvious (Ayeb-Zakhama, 2015).

\section{Characters measured and statistical analysis}

Percentage germination, root and shoot length of seedling of each target species were determined in each petri dish on day 8 after depositing the seeds on the medium. Data of allelopathy assay were subjected to the One way-ANOVA using XLSTAT 2016 
software. Means were compared at the 0.05 significance level by Duncan's new multiple range test. The inhibitory percent was computed using the following equation specified by Chung et al. (2001):

$$
\text { Inhibition }(\%)=[(\text { extract }- \text { control }) / \text { control }] \times 100
$$

where 'extract' is the trait determined by the existence of the seed extract and 'control' is the parameter calculated in the presence of distilled water.

\section{Results and discussion}

\section{Chemical composition of chickpea seeds}

GC/MS analysis supplied supplementary visions into phytotoxin-mediated suppression of the tested species by determining the qualitative and quantitative manifestation of diverse components. The volatile constituents noticed from the seeds of the plants and their percentage contribution are displayed in Table 1.

Table 1. Constituents of the extracts from seeds of black desi and kabuli chickpea

\begin{tabular}{|c|c|c|}
\hline Compounds & $\begin{array}{c}\text { Black desi seeds } \\
\text { Concentration } \\
(\%)\end{array}$ & $\begin{array}{c}\text { Kabuli seeds } \\
\text { Concentration } \\
(\%)\end{array}$ \\
\hline Eugenol & 86.35 & 89.67 \\
\hline Beta Caryophyllene & 6.56 & - \\
\hline Alpha Caryophyllene & 1.53 & - \\
\hline 1,4,7, -Cycloundecatriene, 1,5,9,9-tetramethyl-, Z,Z,Z- & 0.13 & - \\
\hline Caryophyllene oxide & 5.24 & - \\
\hline Isoaromadendrene epoxide & 0.11 & - \\
\hline cis-Z- $\alpha$-Bisabolene epoxide & 0.08 & - \\
\hline Benzoic acid, 2,5-bis(trimethylsiloxy)-, trimethylsilyl ester & - & 0.51 \\
\hline 1-Triethylsilyloxyheptadecane & - & 0.71 \\
\hline Methoxy acetic acid, 3-tridecyl ester & - & 3.47 \\
\hline Pterin-6-carboxylic & - & 0.19 \\
\hline Tetradecane & - & 0.11 \\
\hline Aristolone & - & 1.25 \\
\hline $\begin{array}{l}\text { 2H-Cyclopropa[g]benzofuran, 4,5,5a,6,6a,6b-hexahydro-4,4,6b- } \\
\text { trimethyl-2-(1-methylethenyl)- }\end{array}$ & - & 0.75 \\
\hline $\begin{array}{l}\text { 4-(3,3-Dimethyl-but-1-ynyl)-4-hydroxy-2,6,6-trimethylcyclohex-2- } \\
\text { enone }\end{array}$ & - & 1.22 \\
\hline Propiolic acid, 3-(1-hydroxy-2-isopropyl-5-methylcyclohexyl)- & - & 0.88 \\
\hline $\begin{array}{l}\text { 5-(7a-Isopropenyl-4,5-dimethyl-octahydroinden-4-yl)-3-methyl-pent-2- } \\
\text { enal }\end{array}$ & - & 0.63 \\
\hline $\begin{array}{l}\text { 5-(7a-Isopropenyl-4,5-dimethyl-octahydroinden-4-yl)-3-methyl-pent-2- } \\
\text { en-1-ol }\end{array}$ & - & 0.61 \\
\hline Total & 100.00 & 100 \\
\hline
\end{tabular}


Seven and twelve compounds belonging to the volatile compound group were identified in ethanolic seed extracts of kabuli and black desi seeds, respectively. A number of volatile constituents responsible for the inhibitory allelopathic motion of chickpea were recognized in the current investigation; none of them previously stated. Chemical investigates manifested the presence of predominated compounds: eugenol, beta caryophyllene and caryophyllene oxide in ethanolic extracts of black desi seeds while kabuli seeds chickpea were rich in eugenol and methoxy acetic acid, 3-tridecyl ester. The inhibition effect of caryophyllene and eugenol compounds on the germination parameters, was previously characterized in several plant species (Singh et al., 2008; Ayeb-Zakhama et al., 2016).

\section{Allelopathic effect of black desi seeds extract}

Statistical investigation of the data demonstrated significant effect of the ethanolic extract of distinct concentrations of black desi seeds on germination (\%) of various plant species (Table 2).

Table 2. Allelopathic effect of different concentrations of black desi seeds extracts on germination percentage and seedling growth of test species

\begin{tabular}{c|c|c|c|c}
\hline Plant species & Parameters & Control & $\mathbf{2 . 0 0} \mathbf{~ m g} / \mathbf{m l}$ & $\mathbf{4 . 0 0} \mathbf{~ m g} / \mathbf{m l}$ \\
\hline \multirow{3}{*}{ Common vetch } & Germination $(\%)$ & $91.10 \mathrm{a}$ & $75.55 \mathrm{ab}$ & $44.44 \mathrm{~b}$ \\
& Root Length $(\mathrm{cm})$ & $1.37 \mathrm{a}$ & $0.74 \mathrm{~b}$ & $0.48 \mathrm{~b}$ \\
& Shoot Length $(\mathrm{cm})$ & $1.15 \mathrm{a}$ & $0.10 \mathrm{~b}$ & $0.06 \mathrm{~b}$ \\
\hline \multirow{3}{*}{ Wild mustard } & Germination $(\%)$ & $51.00 \mathrm{a}$ & $0.00 \mathrm{~b}$ & $0.00 \mathrm{~b}$ \\
& Root Length $(\mathrm{cm})$ & $1.02 \mathrm{a}$ & $0.00 \mathrm{~b}$ & $0.00 \mathrm{~b}$ \\
& Shoot Length $(\mathrm{cm})$ & $1.70 \mathrm{a}$ & $0.00 \mathrm{~b}$ & $0.00 \mathrm{~b}$ \\
\hline \multirow{3}{*}{ Narbon vetch } & Germination $(\%)$ & $95.55 \mathrm{a}$ & $95.55 \mathrm{a}$ & $37.78 \mathrm{~b}$ \\
& Root Length $(\mathrm{cm})$ & $3.69 \mathrm{a}$ & $0.515 \mathrm{~b}$ & $0.16 \mathrm{~b}$ \\
& Shoot Length $(\mathrm{cm})$ & $4.49 \mathrm{a}$ & $0.40 \mathrm{~b}$ & $0.00 \mathrm{~b}$ \\
\hline \multirow{2}{*}{ Kabuli chickpea } & Germination $(\%)$ & $97.78 \mathrm{a}$ & $55.55 \mathrm{~b}$ & $17.77 \mathrm{c}$ \\
& Root Length $(\mathrm{cm})$ & $2.55 \mathrm{a}$ & $0.29 \mathrm{~b}$ & $0.06 \mathrm{~b}$ \\
& Shoot Length $(\mathrm{cm})$ & $0.89 \mathrm{a}$ & $0.07 \mathrm{~b}$ & $0.00 \mathrm{~b}$ \\
\hline
\end{tabular}

Means connected by different letters within one or same row vary significantly at $(P<5 \%)$ by Duncan's new multiple range test.

The black desi seeds extract means separation displayed that highest germination was noted for control treatment (no extract) in all plant species, which was statistically different with the germination percentage obtained from the concentrations of 2.00 and $4.00 \mathrm{mg} / \mathrm{ml}$ (Fig. 2). In common vetch, the values of germination percentage, root length and shoot length were ranged between $44.44-91.10 \%, 0.48-1.37 \mathrm{~cm}$, and 0.06$1.15 \mathrm{~cm}$, respectively. For wild mustard, the values of germination percentage, root length and shoot length were varied from 0.00 to $51.00 \%, 0.00$ to $1.02 \mathrm{~cm}$, and 0.00 to $1.70 \mathrm{~cm}$, respectively. The germination percentage, root length and shoot length in narbon vetch was recorded between $37.78-95.55 \%, 0.16-3.69 \mathrm{~cm}$, and $0.00=4.49 \mathrm{~cm}$, respectively. On the other hand, the data for the plant species mean revealed that the percent germination of the all tested species was significantly affected, especially wild 
mustard that gave a minimum germination against the tested extracts. The highest root and shoot lengths was recorded by control, which is statistically varies from the concentrations 2.00 and $4.00 \mathrm{mg} / \mathrm{ml}$. Concerning the effect of black desi seeds extract on the germination parameters of kabuli chickpea, the results revealed a range between $17.77-97.78 \%, 0.06-2.55 \mathrm{~cm}$, and $0.00-0.89 \mathrm{~cm}$ for germination percentage, root length and shoot length, respectively.

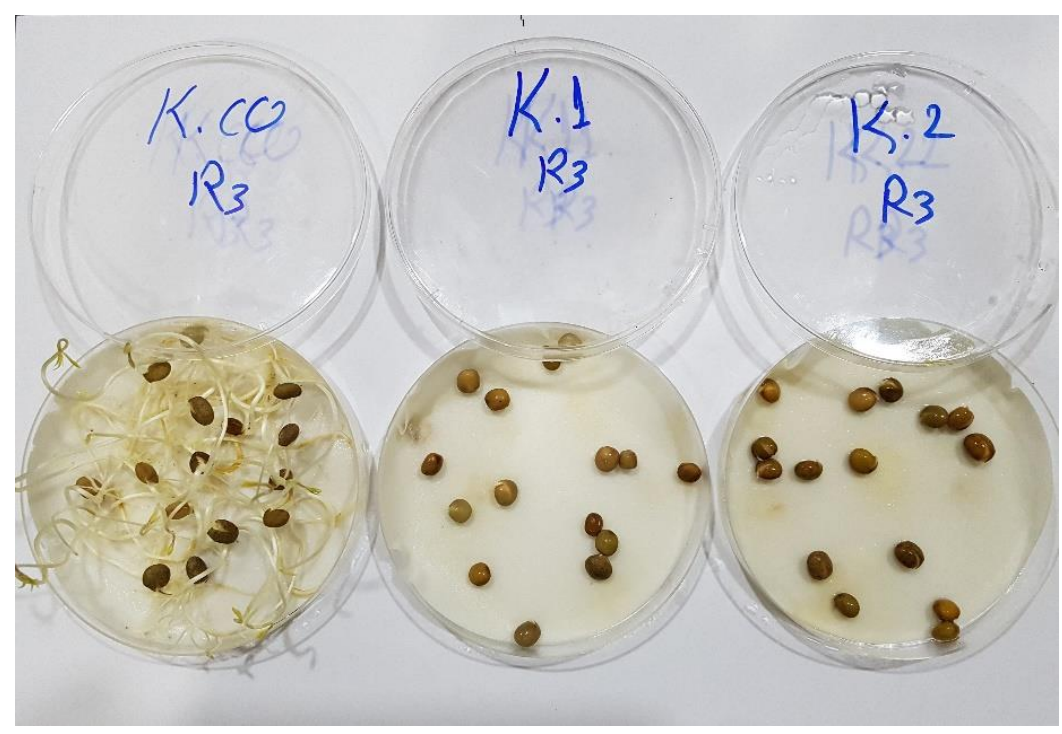

Figure 2. Allelopathic effect of black desi seeds extracts on germination traits of narbon vetch on filter paper. K. co: control, K.1: $2.00 \mathrm{mg} / \mathrm{ml}$ and $K .2: 4.00 \mathrm{mg} / \mathrm{ml}$

The inhibition of germination by the different concentration of extract ranged from 17.07 to $51.22 \%$ for common vetch, from 100.00 to $100.00 \%$ for wild mustard, from 0.00 to $60.88 \%$ for wild narbon vetch and from 40.12 to 81.825 for kabuli chickpea (Table 3).

Table 3. Inhibition percentage of black desi seeds extract on germination percentage and seedlings elongations of test species

\begin{tabular}{c|c|c|c|c}
\hline Plant species & Parameters & Control & $\mathbf{2 . 0 0} \mathbf{~ m g} / \mathbf{m l}$ & $\mathbf{4 . 0 0} \mathbf{~ m g} / \mathbf{m l}$ \\
\hline \multirow{3}{*}{ Common vetch } & Germination (\%) & 0.00 & 17.07 & 51.22 \\
& Root length (cm) & 0.00 & 46.20 & 48.84 \\
& Shoot length (cm) & 0.00 & 91.62 & 99.51 \\
\hline \multirow{3}{*}{ Wild mustard } & Germination (\%) & 0.00 & 100.00 & 100.00 \\
& Root length (cm) & 0.00 & 100.00 & 100.00 \\
& Shoot length (cm) & 0.00 & 100.00 & 100.00 \\
\hline \multirow{3}{*}{ Narbon vetch } & Germination (\%) & 0.00 & 0.00 & 60.88 \\
& Root length (cm) & 0.00 & 86.05 & 95.69 \\
& Shoot length (cm) & 0.00 & 91.18 & 100.00 \\
\hline \multirow{3}{*}{ Kabuli chickpea } & Germination (\%) & 0.00 & 43.19 & 81.82 \\
& Root length (cm) & 0.00 & 88.71 & 97.65 \\
& Shoot length (cm) & 0.00 & 99.25 & 100.00 \\
\hline
\end{tabular}


This result marked that the negative influence of $4.00 \mathrm{mg} / \mathrm{ml}$ on the germination parameters was stronger than $2.00 \mathrm{mg} / \mathrm{ml}$. On the other hand, the inhibition of different extracts on the root elongation varied from 46.20 to $48.84 \%$ for common vetch, from 100.00 to $100.00 \%$ for wild mustard, from 86.05 to $95.69 \%$ for wild vetch and from 88.71 to $97.65 \%$ for kabuli seed chickpea. The highest inhibition percentage in shoot lengths of 7-day-old treated seedlings of all plant species were observed in the concentration of $4.00 \mathrm{mg} / \mathrm{ml}$. In all circumstances, the target plants were critically inhibited by the diverse extracts and this inhibition differed depending on target species. Among all studied parameters, the shoot growth in all plant species was more affected by black desi seed extracts.

In effect, Prati and Bossdorf described that the grade of allelopathic obstacle is species-specific and can even differ within a species (Prati and Bossdorf, 2004). Germination is generally used as a factor to identify the phytotoxicity, but the results of current research offered that early seedling growth is affected to a great degree by extracts tested. Similar to our work, numerous researchers have stated that seedling growth is more sensitive to allelochemical compounds than germination (Einhellig, 1985; Ayeb et al., 2013; Wu et al., 2015). The different allelopathic properties can be ascribed to the diverse chemical configuration of the extracts, and in particular to the content of volatile compounds, reported in the specific literature as powerful germination inhibitors (Macias et al., 2003; Reigosa et al., 2006; Formisano et al., 2007). The attendance of allelochemicals constituents and their amounts has been investigated many times and many researchers are of the view that allelochemical have existed in diverse parts of plants and can greatly influence the host plants in many ways. However, allelochemicals are produced in plants as secondary metabolites and situated in some particular organs of donor plants.

\section{Allelopathy impact of kabuli seed}

The extract of kabuli seeds of chickpea produced a significant impact on germination percentage of all plant species (Table 4). In common vetch, the lowest germination was recorded in seeds treated with extract at 2.00 and $4.00 \mathrm{mg} / \mathrm{ml}$. Common vetch root and shoot elongation were reduced by nearly $100 \%$ when they were subjected to kabuli-type extract.

Table 4. Impact of diverse concentrations of kabuli seeds extracts on germination percentage and seedling length parts of test species

\begin{tabular}{c|c|c|c|c}
\hline Plant species & Parameters & Control & $\mathbf{2 . 0 0} \mathbf{~ m g} / \mathbf{m l}$ & $\mathbf{4 . 0 0} \mathbf{~ m g} / \mathbf{m l}$ \\
\hline \multirow{3}{*}{ Common vetch } & Germination $(\%)$ & $91.10 \mathrm{a}$ & $0.00 \mathrm{~b}$ & $0.00 \mathrm{~b}$ \\
& Root Length $(\mathrm{cm})$ & $1.37 \mathrm{a}$ & $0.00 \mathrm{~b}$ & $0.00 \mathrm{~b}$ \\
& Shoot Length $(\mathrm{cm})$ & $1.16 \mathrm{a}$ & $0.00 \mathrm{~b}$ & $0.00 \mathrm{~b}$ \\
\hline \multirow{3}{*}{ Wild mustard } & Germination $(\%)$ & $51.00 \mathrm{a}$ & $0.00 \mathrm{~b}$ & $0.00 \mathrm{~b}$ \\
& Root Length $(\mathrm{cm})$ & $1.02 \mathrm{a}$ & $0.00 \mathrm{~b}$ & $0.00 \mathrm{~b}$ \\
& Shoot Length $(\mathrm{cm})$ & $17.00 \mathrm{a}$ & $0.00 \mathrm{~b}$ & $0.00 \mathrm{~b}$ \\
\hline \multirow{3}{*}{ Narbon vetch } & Germination $(\%)$ & $95.55 \mathrm{a}$ & $95.55 \mathrm{a}$ & $6.67 \mathrm{~b}$ \\
& Root Length $(\mathrm{cm})$ & $3.36 \mathrm{a}$ & $0.78 \mathrm{~b}$ & $0.08 \mathrm{~b}$ \\
& Shoot Length $(\mathrm{cm})$ & $4.49 \mathrm{a}$ & $0.38 \mathrm{~b}$ & $0.00 \mathrm{~b}$ \\
\hline \multirow{3}{*}{ Chickpea black desi } & Germination $(\%)$ & $97.77 \mathrm{a}$ & $0.00 \mathrm{~b}$ & $0.00 \mathrm{~b}$ \\
& Root Length $(\mathrm{cm})$ & $2.20 \mathrm{a}$ & $0.00 \mathrm{~b}$ & $0.00 \mathrm{~b}$ \\
& Shoot Length $(\mathrm{cm})$ & $0.48 \mathrm{a}$ & $0.00 \mathrm{~b}$ & $0.00 \mathrm{~b}$ \\
\hline
\end{tabular}

Means connected by different letters within one or same row vary significantly at $(P<5 \%)$ by Duncan's new multiple range test. 
All the traits of wild mustard, germination and seedling growth, were adversely influenced by the treatment of seed extracts of kabuli chickpea seeds (Table 5). A reduction of $100 \%$ of germination percentage and growth elongation was observed in wild mustard. The application of the kabuli seed extract, in wild vetch, depicted about $0.00-93.02 \%$ reduction in germination percentage, $77.34-97.71 \%$ in root length, whereas reduction in shoot length was 91.50 and $100 \%$ for concentration 2.00 and 4.00 $\mathrm{mg} / \mathrm{ml}$, respectively. In contrast, kabuli seed extracts at $2.00 \mathrm{mg} / \mathrm{ml}$ produced nonsignificant germination percentage with the control. Likewise, the germination percentage, root and shoot length of black desi chickpea, individually were also severely influenced by kabuli seed extract depicting $100 \%$ reduction over control. The results of this section indicated that inhibition of germination, enlarged with rising concentrations of extracts of seeds. The maximum reduction in germination percentage of plant species at $4.00 \mathrm{mg} / \mathrm{ml}$ concentration could be due to more inhibitory effect of phytotoxic or allelochemicals present in seeds. An indirect relationship between a minor germination percent and allelopathic inhibition may be the consequence of alteration in the water uptake and synthesis of gibberellic acid, which regulates de novo amylase production during seed germination (Tawaha and Turk, 2003; Shanee et al., 2011; Muzell Trezzi et al., 2016; Tahir et al., 2018).

The significant decreasing in shoot and root elongation of plant species seedlings by different concentrations of seed extracts could be caused by the presence of ethanol soluble inhibitors (Yun and Kil, 1992; Shanee et al., 2011). These inhibitors include numerous substances like phenolic, terpenoids, organic acids, or alkaloids and essential compounds which act as allelochemicals and influence germination and seedling growth. Allelochemicals decrease the elongation, expansion, and division of cells, all of which are grown prerequisites, and they inhibit absorption of ions and therefore arrest growth and repress protein synthesis and/or stimulate its degradation.

Varying the rate of inhibition of plant species seedling growth with ethanolic extracts of chickpea seeds at both concentrations indicates that inhibitory effects of chickpea differed with genotypes and extract concentration. Depending on the current investigations, it could be settled that ethanolic extract of chickpea seeds had detrimental consequences on seed germination and seedling elongation of plant species that augmented with increasing concentration. Seed extracts of chickpea enclose compound in its tissues which may provoke phytotoxic influence under field conditions without depletion of available soil nutrients.

Table 5. Inhibition percentage of kabuli seeds extract on percentage of germination, root length and shoot length of test specie

\begin{tabular}{c|c|c|c|c}
\hline Plant species & Parameters & Control & $\mathbf{2 . 0 0} \mathbf{~ m g} / \mathbf{m l}$ & $\mathbf{4 . 0 0} \mathbf{~ m g} / \mathbf{m l}$ \\
\hline \multirow{3}{*}{ Common vetch } & Germination $(\%)$ & 0.00 & 100.00 & 100.00 \\
& Root length (cm) & 0.00 & 100.00 & 100.00 \\
& Shoot length (cm) & 0.00 & 100.00 & 100.00 \\
\hline \multirow{3}{*}{ Wild mustard } & Germination (\%) & 0.00 & 100.00 & 100.00 \\
& Root length (cm) & 0.00 & 100.00 & 100.00 \\
& Shoot length (cm) & 0.00 & 100.00 & 100.00 \\
\hline \multirow{3}{*}{ Narbon vetch } & Germination $(\%)$ & 0.00 & 0.00 & 93.02 \\
& Root length (cm) & 0.00 & 77.34 & 97.71 \\
& Shoot length (cm) & 0.00 & 91.50 & 100.00 \\
\hline \multirow{3}{*}{ Chickpea black desi } & Germination $(\%)$ & 0.00 & 100.00 & 100.00 \\
& Root length $(\mathrm{cm})$ & 0.00 & 100.00 & 100.00 \\
& Shoot length (cm) & 0.00 & 100.00 & 100.00 \\
\hline
\end{tabular}


In comparative analysis, wild mustard was more sensitive to black desi seeds extracts tested than other species. In overall, the results of Table 6 demonstrated that the differences between kabuli and desi extracts showed a non-significant effect on the germination characters of narbon vetch and wild mustard at 5\% level. On the other hand, kabuli seeds extract had the highest significant inhibition on germination percentage and root length of common vetch.

Table 6. Average comparison for germination characters of common vetch, wild mustard and narbon vetch affected by the allelopathic potential of black desi and kabuli extracts

\begin{tabular}{c|c|c|c}
\hline Weed species & Traits & Black desi extract & Kabuli extract \\
\hline \multirow{3}{*}{ Common vetch } & Germination $(\%)$ & $59.99 \mathrm{~b}$ & $0.00 \mathrm{a}$ \\
& Root length $(\mathrm{cm})$ & $0.61 \mathrm{~b}$ & $0.00 \mathrm{a}$ \\
& Shoot length $(\mathrm{cm})$ & $0.51 \mathrm{a}$ & $0.00 \mathrm{a}$ \\
\hline \multirow{3}{*}{ Wild mustard } & Germination $(\%)$ & $0.00 \mathrm{a}$ & $0.00 \mathrm{a}$ \\
& Root length $(\mathrm{cm})$ & $0.00 \mathrm{a}$ & $0.00 \mathrm{a}$ \\
& Shoot length $(\mathrm{cm})$ & $0.00 \mathrm{a}$ & $0.00 \mathrm{a}$ \\
\hline \multirow{3}{*}{ Narbon vetch } & Germination $(\%)$ & $66.67 \mathrm{a}$ & $51.11 \mathrm{a}$ \\
& Root length $(\mathrm{cm})$ & $0.34 \mathrm{a}$ & $0.43 \mathrm{a}$ \\
& Shoot length $(\mathrm{cm})$ & $1.98 \mathrm{a}$ & $1.91 \mathrm{a}$ \\
\hline
\end{tabular}

Means connected by different letters within one or same row vary significantly at $(P<5)$ by Duncan's new multiple range test.

\section{Conclusions}

The outcomes of current study showed that both types of chickpea contained high amounts of eugenol. In addition, the results exhibited the variations in the chemical composition profile of both extracts. The results stated that all seed extracts displayed significant allelopathic impact, and the degree of inhibition of seedling growth diverse from species to species. These negative effects were dose dependent. Ethanol soluble allelochemicals in both kabuli and desi seed extracts inhibited the germination and seedling elongations of the tested plant species. Based on the results, it can be concluded that both types of chickpea showed good allelopathic activity that may be used in the future herbicide screening program prior to launch in the market.

\section{REFERENCES}

[1] Asif, M., Rooney, L. W., Ali, R., Riaz, M. N. (2013): Application and opportunities of pulses in food system. A review. - Crit. Rev. Food Sci. Nutr. 53(11): 1168-1179.

[2] Ayeb, A. E. L., Jannet, H. B., Skhiri, F. H. (2013): Effects of Acacia cyanophylla Lindl. extracts on seed germination and seedling growth of four crop and weed plants. - Turk. J. Biol. 37(3): 305-314.

[3] Ayeb-Zakhama, A. E. (2015): Phytochemical and phytotoxic investigation of the flowers from Citharexylum spinosum L. - Ind. Crops Prod. 76: 653-659.

[4] Ayeb-Zakhama, A. E., Sakka-Rouis, L., Bergaoui, A., Flamini, G., Jannet, H. B., Harzallah-Skhiri, F. (2016): Chemical composition and allelopathic potential of essential oils from Tipuana tipu (Benth.) Kuntze cultivated in Tunisia. - Chem. Biodivers. 13(3): 309-318. 
[5] Chibbar, R. N., Ambigaipalan, P., Hoover, R. (2010): Review: Molecular diversity in pulse seed starch and complex carbohydrates and Its role in human nutrition and health. Cereal Chem. J. 87(4): 342-352.

[6] Chung, I. M., Ahn, J. K., Yun, S. J. (2001): Assessment of allelopathic potential of barnyard grass (Echinochloa crus-galli) on rice (Oryza sativa L.) cultivars. - Crop Prot. 20(10): 921-928.

[7] Einhellig, F. A. (1985): Effects of Allelopathic chemicals on crop productivity. - In: Hedin, P. A. (ed.) Bioregulators for pest control, ACS Symposium series, 0097-6156, American Chemical Society, Washington, D.C. 276: 109-130.

[8] el-Adawy, T. A. (2002): Nutritional composition and antinutritional factors of chickpeas (Cicer arietinum L.) undergoing different cooking methods and germination. - Plant Foods Hum. Nutr. 57(1): 83-97.

[9] Formisano, C., Rigano, D., Senatore, F., Feo, V. D., Bruno, M., Rosselli, S. (2007): Composition and allelopathic effect of essential oils of two thistles Cirsium creticum (Lam.) D.'Urv. ssp. triumfetti (Lacaita) Werner and Carduus nutans L. - J. Plant Interact. 2(2): 115-120.

[10] Jukanti, A. K., Gaur, P. M., Gowda, C. L. L., Chibbar, R. N. (2012): Nutritional quality and health benefits of chickpea (Cicer arietinum L.). A review. - Br. J. Nutr. 108(S1): S11-S26.

[11] López-Cortez, M. D. S., Rosales-Martínez, P., Arellano-Cárdenas, S., Cornejo-Mazón, M. (2016): Antioxidants properties and effect of processing methods on bioactive compounds of legumes. In: Goyal, A. K. (ed.), Grain Legumes, InTech.

[12] Macias, F. A., Galindo, J. C. G., Molinillo, M. G., Cutler, H. G. J. (2003): Allelopathy: Chemistry and mode of action of allelochemicals. - CRC Press.

[13] Mahajan, G., Ramesha, M. S., Chauhan, B. S. (2014): Response of rice genotypes to weed competition in dry direct-seeded rice in India. - Sci. World J. 2014p. 641589.

[14] Muzell Trezzi, M., Vidal, R. A., Balbinot Junior, A. A., Hertwig Bittencourt, H., vonda Silva Souza Filho, A. P. (2016): Allelopathy. Driving mechanisms governing its activity in agriculture. - J. Plant Interact. 11(1): 53-60.

[15] Prati, D., Bossdorf, O. (2004): Allelopathic inhibition of germination by Alliaria petiolata (Brassicaceae). - Am. J. Bot. 91(2): 285-288.

[16] Reigosa, M. J., Pedrol, N., González, L. (2006): Allelopathy. - Kluwer Academic Publishers, Dordrecht.

[17] Shanee, S., Tanveer, A., Javaid, M. M., Chaudhry, K. M., Aziz, A., Khaliq, A., Chaudhry, M. N., Pervez, M. A., Awan, I. U. (2011): Phytotoxic effects of Euphorbia dracunculoides. A weed of rainfed chickpea-chickpea cropping system. - Span. J. Agric. Res. 9(2): 580-588.

[18] Singh, H. P., Batish, D. R., Kohli, R. K. (2008): Allelopathy in agroecosystems. - J. Crop Prod 4(2): 1-41.

[19] Smýkal, P., Coyne, C. J., Ambrose, M. J., Maxted, N., Schaefer, H., Blair, M. W., Berger, J., Greene, S. L., Nelson, M. N., Besharat, N., Vymyslický, T., Toker, C., Saxena, R. K., Roorkiwal, M., Pandey, M. K., Hu, J., Li, Y. L., Wang, L. X., Guo, Y., Qiu, L. J., Redden, R. J., Varshney R. K. (2015): Legume crops phylogeny and genetic diversity for science and breeding. - Crit Rev Plant Sci 34(1-3): 43-104.

[20] Tahir, N. A., Qader, K. O., Azeez, H. A., Rashid, J. S. (2018): Inhibitory allelopathic effects of Moringa oleifera Lamk plant extracts on wheat and Sinapis arvensis L. Allelopathy Journal 44(1): 35-48.

[21] Tawaha, A. M., Turk, M. A. (2003): Allelopathic effects of black mustard (Brassica nigra) on germination and growth of wild barley (Hordeum spontaneum). - J. Agron. Crop Sci. 189(5): 298-303.

[22] Vogt, G. A., Balbinot Junior, A. A., Trezzi, M. M., Backes, R. L., Nicknich, W. (2013): Competitive ability of black common bean genotypes with weeds. - Ciênc. Agrotec. 37(5): 397-403. 
[23] Wu, A. P., Li, Z. L., He, F. F., Wang, Y. H., Dong, M. (2015): Screening allelochemicalresistant species of the Alien Invasive Mikania micrantha for restoration in South China. - PLoS ONE 10 (7e0132967).

[24] Xu, B., Chang, S. K. C. (2010): Phenolic substance characterization and chemical and cell-based antioxidant activities of 11 lentils grown in the northern United States. - J. Agric. Food Chem. 58(3): 1509-1517.

[25] Yadav, S. S., Redden, R. J., Chen, W., Sharma, B. (2007): Chickpea breeding and management. - CABI, Wallingford.

[26] Yun, K. W., Kil, B. S. (1992): Assessment of allelopathic potential in Artemisia princeps var. Orientalis residues. - J. Chem. Ecol 18(11): 1933-1940. 